\title{
PELATIHAN GURU PEMBIMBING OLIMPIADE MATEMATIKA SEKOLAH DASAR VIA DARING
}

\author{
Ikhbariaty Kautsar Qadry ${ }^{*}$ \\ Nursakiah ${ }^{2}$ \\ Kristiawati $^{3}$ \\ 1,2,3 Universitas Muhammadiyah Makassar \\ ikhbariaty.qadry@unismuh.ac.id ${ }^{1^{*}}$ \\ nursakiah@unismuh.ac.id ${ }^{2)}$ \\ kristiawati@unismuh.ac.id ${ }^{3}$
}

Kata Kunci:
[Pelatihan guru,
Olimpiade
matematika]

Published by:

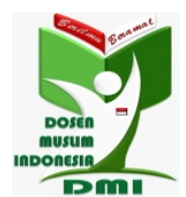

Abstrak: Hasil analisis situasi menunjukkan bahwa guru SD di Kecamatan Walenrang Timur, Kabupaten Luwu butuh kemampuan menganalisis dan memecahkan soal olimpiade matematika SD agar mereka bisa membimbing dan mengarahkan siswa yang akan mengikuti olimpiade. Kegiatan ini bertujuan membekali guru kemampuan menganalisis dan memecahkan soal olimpiade matematika SD via daring. Masalah mitra diselesaikan dengan metode pelatihan. Prosedur kerja metode tersebut, yaitu: pemberian angket sebelum pelatihan, tes awal untuk semua peserta pelatihan, penyajian materi penyelesaian soal olimpiade matematika SD via daring, tes akhir untuk semua peserta pelatihan, pemberian angket setelah pelatihan. Kegiatan ini diikuti oleh 23 peserta dari 11 sekolah dasar berbeda se-Kecamatan Walinrang Timur, Kabupaten Luwu. Hasil angket menunjukkan bahwa kemantapan kemampuan menganalisis dan mengerjakan soal olimpiade matematika peserta mengalami peningkatan dari $50 \%$ sebelum pelatihan menjadi $69,6 \%$ setelah pelatihan. Melalui angket, peserta mengakui mendapat banyak pengetahuan dan pengalaman dalam berinteraksi dengan soal olimpiade matematika. Selain itu, kegiatan ini, menurut mereka, adalah ajang silaturahim antara pemateri dan peserta, terutama dalam membangun dan mengembangkan profesionalitas mereka sebagai pendidik matematika.

Copyright (C) 2021 The Author(s)

This article is licensed under CC BY 4.0 License (cc) $\mathrm{BY}$

https://dmi-journals.org/jai 


\section{Pendahuluan}

Era globalisasi menyebabkan kompetisi di berbagai aspek kehidupan. Hal ini menjadi motif bagi banyak pihak untuk meningkatkan kemampuan dan membuat perencanaan strategis untuk menatap masa depan yang cerah. Strategi utama yang harus segera dibenahi dalam meningkatkan kapasitas adalah peningkatan Sumber Daya Manusia yang berkualitas agar mampu bersaing di segala lini (Rohim \& Sari, 2019).

Olimpiade sains nasional tingkat sekolah dasar dan atau yang sederajat telah dirintis sejak sekitar 18 tahun yang lalu. Ajang ini diadakan sebagai langkah turut andil dalam program peningkatan kualitas sumber daya manusia. Ini adalah suatu kegiatan yang menjadi wadah penting bagi pengembangan kemampuan berpikir kritis, kemampuan memecahkan masalah, kreativitas, dan sportivitas siswa (Wiyoko dkk, 2019).

Sebenarnya, tujuan khusus ajang olimpiade tingkat sekolah dasar adalah sebagai wahana pengembangan bakat dan minat siswa sekolah dasar dalam bidang matematika. Melalui ajang ini, mereka diharapkan dapat berkreasi serta melakukan inovasi sesuai kemampuannya. Selain itu, ajang ini juga diharapkan dapat memotivasi mereka agar senantiasa mendorong adanya peningkatan kecerdasan emosional dan spiritual berdasarkan norma-norma yang sehat dan dapat memacu kemampuan berpikir mereka. Akhirnya, ajang ini diharapkan dapat menjaring bibit unggul dan berprestasi yang akan menjadi peserta olimpiade matematika tingkat internasional (Suryawan dkk, 2017).

Bahan yang diujikan dalam olimpiade sebenarnya berasal dari kurikulum yang berlaku pada mata pelajaran matematika, buku-buku pelajaran, buku-buku penunjang dan bahan lain yang relevan. Adapun soal yang diujikan dalam olimpiade SD adalah soal non rutin dengan tingkat kesulitan yang tinggi untuk ukuran siswa. Dalam menyelesaikan soal olimpiade, siswa dituntut untuk menggunakan seluruh kemampuan matematika yang telah diperoleh di sekolah secara kreatif. Keberhasilan siswa dalam menyelesaikan soal-soal non rutin bergantung pada kreasi dan inovasi mereka dalam menerjemahkan dan merencanakan pemecahan masalah atau soal (Suryawan dkk, 2017).

Keberhasilan siswa dalam menyelesaikan soal-soal non rutin mestinya menjadi perhatian khusus bagaimana guru perlu memberikan atau mengajar soal-soal yang serupa dengan soal olimpiade. Dengan demikian, siswa akan terbiasa dengan soal yang sulit dan memudahkan guru dalam membimbing siswa menyelesaikan soal olimpiade sains. Permasalahan terkait olimpiade matematika masih menjadi sorotan, khususnya di Kabupaten Luwu. Hal tersebut ditunjukkan pada hasil perolehan nilai serta sekolah yang menjadi juara olimpiade sains untuk SD tingkat wilayah Kabupaten Luwu tahun 2019. Berdasarkan hasil perolehan nilai terlihat bahwa yang menjadi juara Olimpiade Matematika merupakan SD yang sama.

Selain itu, berdasarkan hasil wawancara dengan Kepala SDN 347 Lamasi Pantai, Luwu yang menjadi juara olimpiade sains di tingkat Kabupaten Luwu untuk tiga tahun terakhir, sangat sulit bahkan hampir tidak ada peserta atau siswa yang lolos seleksi di tingkat propinsi untuk lanjut ke tingkat nasional. Hal itu karena materi soal olimpiade tingkat propinsi sangat sulit diselesaikan oleh peserta. Permasalahan di atas juga dialami oleh guru pembimbing dua bidang sains, yaitu kesulitan guru dalam menganalisis soalsoal olimpiade sains belum teratasi, sehingga berdampak pada proses pembimbingan siswa dalam menyelesaikan soal olimpiade. Soal olimpiade merupakan soal non rutin 
yang sulit diselesaikan oleh siswa. Dengan demikian, selain persiapan materi dan konsep dasar matematika, siswa atau peserta dituntut untuk membiasakan diri berinovasi dan kreatif menerapkan teori di bidang sains yang telah dikuasainya (Muliani dkk, 2018).

Berdasarkan hal tersebut, perlu adanya pelatihan bagi guru untuk menghadapi soal olimpiade sains nasional bidang studi matematika. Dengan adanya pengabdian masyarakat ini diharapkan mampu membantu guru dalam menganalisis, mengarahkan, serta membimbing siswa yang akan mengikuti seleksi olimpiade.

\section{Metode Pelaksanaan}

Kegiatan ini diselenggarakan dengan melibatkan 23 peserta dari guru-guru di Kabupaten Luwu. Rinciannya adalah SDN 573 Pabatang 3 orang, SDN 66 Dangkang 1 orang, SDN 652 Poringan 1 orang, SDN 642 Pangi 1 orang, SDN 479 Lengkong 3 orang, SDN 478 Barowa 1 orang, SDN 369 Tiromanda 1 orang, SDN 367 Pabbaresseng 1 orang, SDN 347 Lamasi Pantai 9 orang, SDN 256 Pabuntang 1 orang, SDN 100 Singgasari 1 orang, seperti yang ditunjukkan pada Gambar 1. Penentuan peserta tersebut dilakukan setelah identifikasi masalah mitra dan masalah prioritasnya. Untuk itu, tim pengabdi terlebih dahulu berkomunikasi dengan pihak SDN 347 Lamasi Pantai, Kabupaten Luwu untuk berdiskusi dengan kepala sekolah sebagai koordinator mitra untuk mengetahui persoalan yang dihadapi. Hasil analisis situasi berdasarkan diskusi tersebut menunjukkan bahwa guru-guru butuh bekal kemampuan menganalisis dan menyelesaikan soal olimpiade matematika.

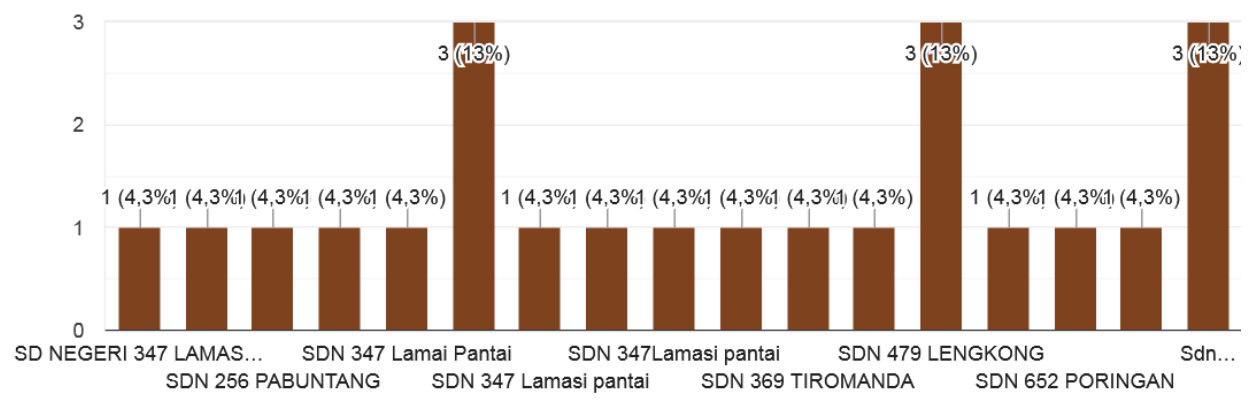

Gambar 1. Asal Sekolah Peserta Pelatihan

Tindak lanjut hasil analisis tersebut adalah penyelenggaraan pelatihan guru pembimbing olimpiade sekolah dasar via daring secara kolektif di SDN 347 Lamasi Pantai melalui aplikasi zoom. 


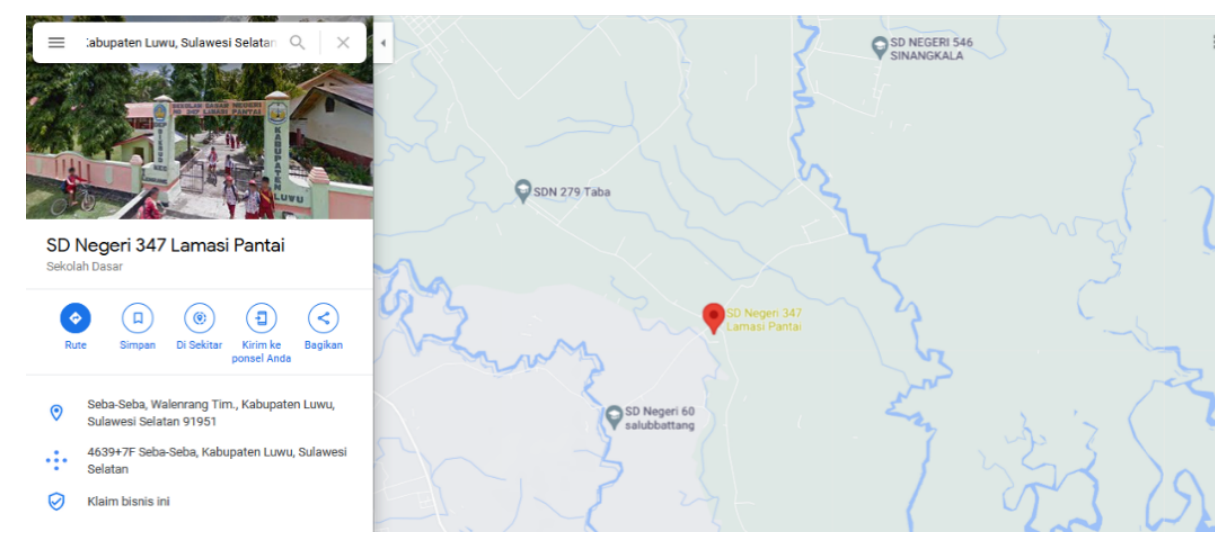

Gambar 2. Lokasi PKM dari Google Map adalah SDN 347 Lamasi Pantai, Kecamatan Walenrang Timur, Kabupaten Luwu

Prosedur kerja pelatihan ini adalah sebagai berikut. Pertama, Angket Respon Peserta sebelum Pelatihan. Kedua, Tes Awal (Pretest) bagi semua peserta pelatihan. Ketiga, Penyajian Materi Penyelesaian Soal Olimpiade Matematika SD. Keempat, Tes Akhir (Posttest) bagi semua peserta pelatihan. Kelima, Angket Respon Peserta setelah Pelatihan. Prosedur pada Tabel 1 menunjukkan deskripsi pelaksanaan kegiatan. Adapun gambaran suasana pelaksanaan pembukaan kegiatan dan kegiatan inti pelatihan adalah seperti yang ditunjukkan pada Gambar 3, sedangkan gambaran hasil kerja guru saat pelatihan adalah seperti yang ditunjukkan pada Gambar 4.

\section{Hasil dan Pembahasan}

Sebelum menyelenggarakan pelatihan, para peserta terlebih dahulu mengisi angket yang disebarkan melalui google form. Melalui angket ini, kita dapat mengetahui secara lebih jelas keikutsertaan mereka dalam kegiatan pelatihan semacam ini dan pengalaman mereka membimbing siswa untuk mengikuti olimpiade. Juga, kita dapat mengetahui kesadaran mereka tentang urgensi melatih siswa berpikir kritis dan kreatif. Selain itu, kita juga dapat mengetahui penilaian mereka terhadap kemampuan mereka sendiri dalam menganalisis dan mengerjakan soal olimpiade matematika.

Tabel 1. Deskripsi Pelaksanaan Kegiatan

\begin{tabular}{|c|c|c|c|}
\hline No & Jenis Kegiatan & Deskripsi Kegiatan & Durasi Kegiatan \\
\hline 1 & $\begin{array}{l}\text { Angket Respon } \\
\text { Peserta sebelum } \\
\text { Pelatihan }\end{array}$ & $\begin{array}{l}\text { Memberikan angket kepada semua } \\
\text { peserta pelatihan }\end{array}$ & $1 / 2 \mathrm{Jam}$ \\
\hline 2 & Tes Awal (Pretest) & $\begin{array}{l}\text { Memberikan pretest kepada semua } \\
\text { peserta pelatihan }\end{array}$ & $1,5 \mathrm{Jam}$ \\
\hline 3 & $\begin{array}{l}\text { Materi Penyelesaian } \\
\text { Soal Olimpiade SD }\end{array}$ & $\begin{array}{l}\text { Pembahasan soal-soal olimpiade } \\
\text { matematika tingkat SD dan diskusi } \\
\text { interaktif peserta dan pemateri } \\
\text { Memberikan posttest kepada semua }\end{array}$ & $3 \mathrm{Jam}$ \\
\hline 4 & $\begin{array}{l}\text { Tes Akhir } \\
\text { (Posttest) }\end{array}$ & $\begin{array}{l}\text { peserta pelatihan untuk } \\
\text { mengetahui kemampuan akhir } \\
\text { mereka setelah pelatihan }\end{array}$ & 1,5 Jam \\
\hline 5 & $\begin{array}{l}\text { Angket Respon } \\
\text { Peserta setelah } \\
\text { Pelatihan }\end{array}$ & $\begin{array}{l}\text { Memberikan angket kepada semua } \\
\text { peserta pelatihan }\end{array}$ & $1 / 2 \mathrm{Jam}$ \\
\hline
\end{tabular}


Hasil angket sebelum pelatihan menunjukkan bahwa dari 23 peserta, 82,6\% di antaranya mengaku belum pernah mengikuti pelatihan seperti yang sedang mereka ikuti dalam kegiatan ini. Namun demikian, 60,9\% dari mereka sudah punya pengalaman membimbing siswa untuk mengikuti olimpiade. Artinya, sebagian dari mereka yang membimbing siswa untuk ikut olimpiade adalah guru-guru yang belum pernah ikut pelatihan semacam ini.

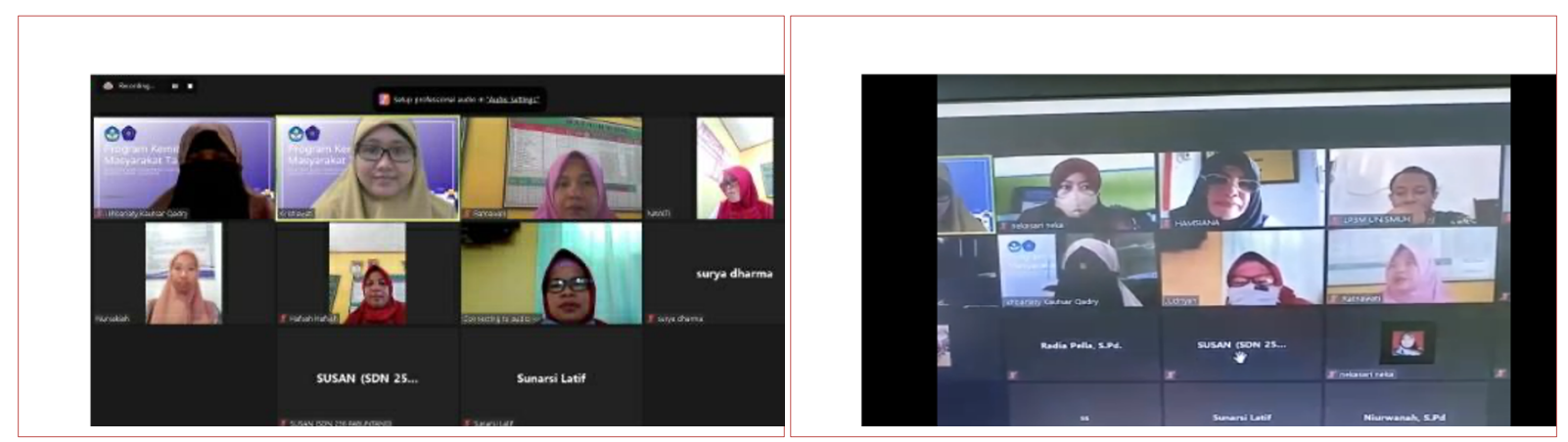

Gambar 3. Suasana Pembukaan Kegiatan oleh Sekretaris LP3M Unismuh dan Suasana Pelaksanaan Pelatihan

Pada dasarnya, seluruh peserta sudah menyadari pentingnya melatih siswa berpikir kritis dan kreatif sebelum pelaksanaan pelatihan ini. Hal ini ditunjukkan oleh hasil angket bahwa 56,5\% selalu menyadari pentingnya mendorong dan melatih siswa berpikir tingkat tinggi tersebut melalui soal matematika non-rutin, seperti soal olimpiade. Sisanya, 30,4\% dari peserta mengaku sering menyadari dan $13 \%$ saja yang kurang menyadari. Sementara itu, dilihat dari penilaian diri mereka sendiri terhadap kemantapan kemampuan mereka dalam menganalisis dan mengerjakan soal olimpiade matematika, 50\% peserta merasa cukup mantap dan sisanya 50\% merasa kurang mantap. Artinya, sebelum pelatihan dilaksanakan, peserta yang merasa cukup mantap dan kurang mantap kemampuannya dalam menganalisis dan mengerjakan soal olimpiade matematika jumlahnya berimbang.

Setelah menyelenggarakan pelatihan, hasil angket peserta menunjukkan bahwa kesadaran akan pentingnya mendorong dan melatih siswa berpikir kritis dan kreatif melalui soal matematika non-rutin, yaitu $60 \%$ selalu menyadari, sering menyadari $30 \%$, dan kurang menyadari $10 \%$. Artinya, ada peningkatan dari sebelum pelatihan, yaitu dari 56,5\% menjadi 60\%. Sementara itu, kemantapan kemampuan menganalisis dan mengerjakan soal olimpiade matematika, yaitu: kurang mantap 30,4\% dan cukup mantap $69,6 \%$. Artinya, ada peningkatan dari sebelum pelatihan, yaitu dari 50\% menjadi $69,6 \%$. 


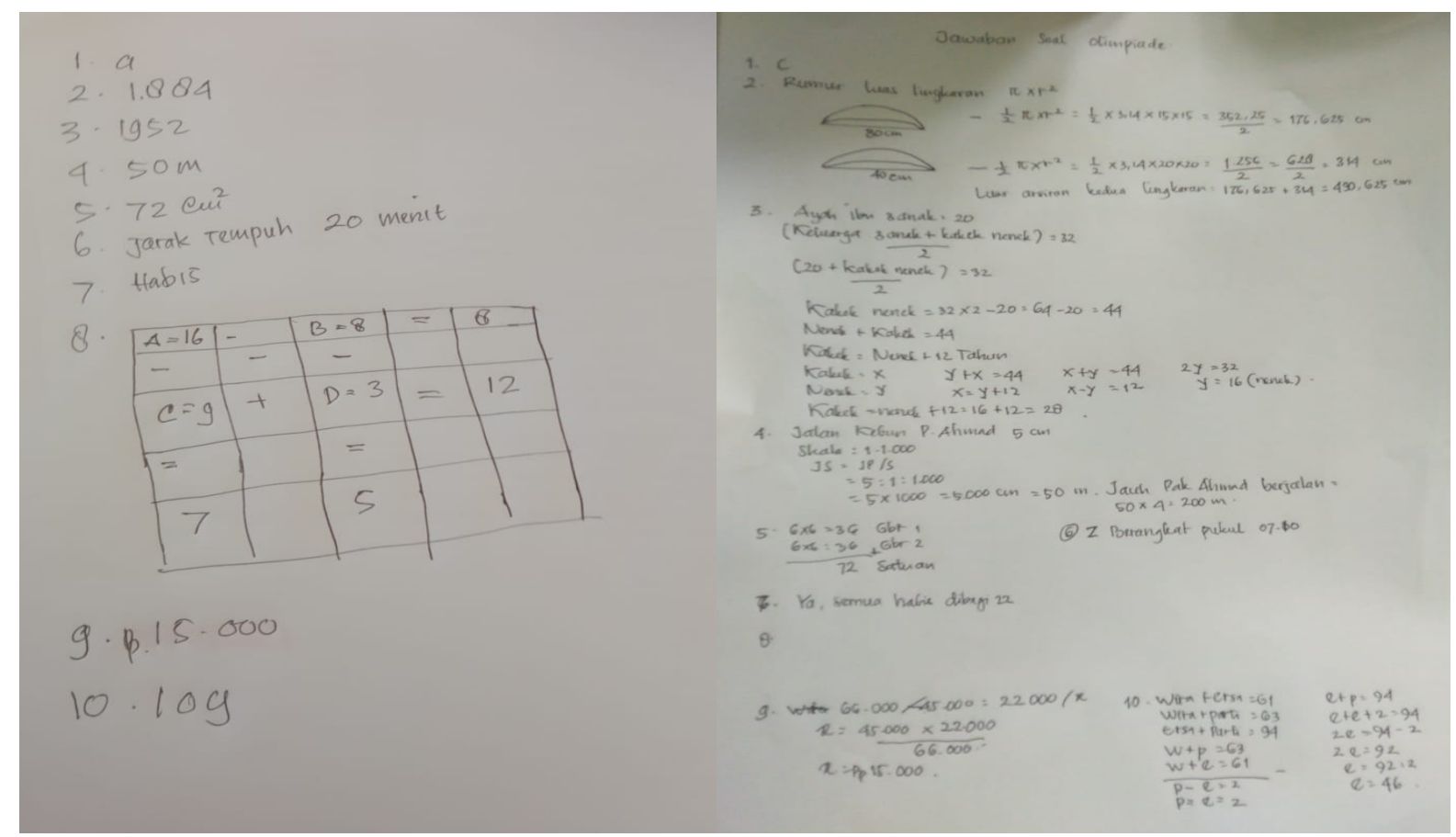

Gambar 3. Sampel Kerja Peserta Pelatihan atas Soal yang Diberikan

Adapun mengenai penjelasan tambahan tentang soal olimpiade matematika yang telah dibahas, $70 \%$ peserta merasa perlu. Sedangkan 30\% peserta bersikap ragu dan tidak ada yang menjawab tidak. Sementara itu, 70\% peserta merasa perlu tambahan jumlah soal olimpiade matematika yang dibahas dan 30\% ragu-ragu apakah perlu tambahan atau tidak. Kemudian mengenai kebutuhan akan kegiatan pemantapan materi-materi matematika yang sekaitan dengan soal olimpiade yang dibahas, $90 \%$ peserta memandang perlu, sedangkan $10 \%$ sisanya ragu-ragu. Selain itu, terkait referensi untuk guru berupa buku dan semacamnya tentang soal olimpiade matematika, 100\% peserta mengatakan perlu. Dalam hal topik matematika yang masih perlu pemantapan, setelah pelatihan peserta merasakan bahwa, bagi mereka, pada dasarnya semua materi matematika butuh latihan. Secara spesifik, para peserta menyarankan beberapa materi yang perlu dilatihkan, yaitu perbandingan, menghitung kecepatan rata-rata, lingkaran, grafik, geometri, bilangan bulat dan pecahan serta operasinya.

Sebagai pemeran utama dalam pembelajaran matematika, para peserta berkomitmen menyukseskan pembelajaran matematika di kelas. Untuk mencapai komitmen mereka itu, para peserta secara umum menyarankan beberapa hal berikut. Satu, memberikan penjelasan secara lebih baik lagi kepada siswa mengenai materi yang dipelajari. Dua, memberikan lebih banyak latihan soal-soal olimpiade. Tiga, melaksanakan bimbingan belajar matematika minimal sekali sepekan di luar jadwal reguler bahkan dengan mendatangkan tenaga pengajar yang berkompeten dalam pembelajaran matematika. Empat, sebagai guru perlu terus belajar agar dapat menguasai materi matematika beserta penggunaan alat peraga yang dibutuhkan terkait materi yang diajarkan, sehingga dapat membelajarkan siswa dan membuat mereka dapat memahami materi pelajaran, bahkan dapat mengerjakan soal berpikir tingkat tinggi. Lima, memotivasi siswa dan mengenalkan manfaat besar dari mempelajari matematika.

\section{Kesimpulan}


Pelatihan ini menampilkan hal baru berupa ruang interaktif yang terbuka seluasnya bagi seluruh peserta, baik menyangkut soal yang diskusikan, maupun menyangkut materi prasyarat dari soal yang didiskusikan. Tentu saja hal baru yang lain adalah terkait dengan pelaksanaan kegiatan full daring. Respon peserta pelatihan melalui angket yang disebarkan menunjukkan bahwa kegiatan ini bermanfaat. Mereka mengaku bahwa penyampaian materi jelas, sehingga mereka mudah memahaminya. Mereka mendapat banyak pengetahuan dan pengalaman dalam berinteraksi dengan soal olimpiade matematika. Selain itu, kegiatan ini, menurut mereka, adalah ajang silaturahim antara pemateri dan peserta, terutama dalam membangun dan mengembangkan profesionalitas pendidik matematika. Untuk itu, mereka sangat berterimakasih kepada tim pengabdi atas waktu dan kesempatan berbagi ilmu dengan mereka.

Selain kelebihan dalam pelaksanaan kegiatan ini, tim pengabdi juga mengakui adanya kelemahan. Sebanyak 8,6\% peserta mengakui bahwa jaringan kurang bersahabat bagi mereka, sehingga penerimaan materi bagi sebagian peserta belum maksimal. Selain itu, Berdasarkan hasil angket berupa saran peserta untuk tim pengabdi, mereka merekomendasikan agar ada lagi pelatihan lanjutan atau bahkan workshop tentang bimbingan penyelesaian soal olimpiade bagi guru. Ini dimaksudkan agar guru bisa menguasai pengerjaan soal tingkat tinggi dan berwawasan luas sebelum membelajarkan berpikir tingkat tinggi pada siswa. Juga, ada yang merekomendasikan pelatihan menemukan cara cepat dan tepat mengerjakan matematika untuk efisiensi waktu. Bahkan ada yang menyarankan teknis pelaksanaan kegiatan dalam bentuk permainan.

\section{Ucapan Terimakasih}

Atas terselenggaranya kegiatan ini, kami ucapkan terima kasih kepada guru-guru dari Kecamatan Walenrang Timur, Kabupaten Luwu yang telah berpartisipasi sebagai peserta dalam kegiatan ini. Khusus guru dan kepala SDN 347 Lamasi Pantai, terima kasih karena telah menjadi mitra yang baik dalam memfasilitasi kegiatan ini, sehingga kegiatan ini dapat terselenggara dengan baik. Terakhir, apresiasi setinggi-tingginya dan terimakasih tak terhingga, kami alamatkan kepada Lembaga Penelitian dan Pengabdian Pada Masyarakat (LP3M) Unismuh Makassar yang telah memberikan dana untuk penyelenggaraan kegiatan ini.

\section{Referensi}

Muliani, F., Noviati, D., \& Fajriani. 2018. Pembinaan Peningkatan Mutu Pendidikan Bidang Olimpiade Sains bagi Guru SD Kota Langsa Provinsi Aceh. Jurnal ABDIMAS Unmer Malang, Vol.3, No.2.

Rohim, M. F. \& Sari, A. F. 2019. Keterampilan Siswa Memecahkan Masalah Olimpiade Matematika Ditinjau dari Kepribadian Tipe Senising dan Intuiting. Jurnal Elemen, Vol.5, No.1.

Suryawan, I. P. P., Gita, I. N., \& Hartawan, IGN. Y. 2017. Peningkatan Kompetensi Siswa Berbakat dalam Bidang Olimpiade Matematika Tingkat SD. Jurnal Widya Laksana, Vol.6, No.2.

Wiyoko, T., Megawati, Aprizan, \& Avana, N. 2019. Peningkatan Kompetensi Siswa Melalui Pembinaan Olimpiade Sains (OSN). Jurnal Warta Lembaga Pengabdian pada Masyarakat, Vol.22, No.2. 